\title{
Financial Learning: Is It The Effective Way to Improve Financial Literacy among Accounting Students?
}

\author{
Nyoman Trisna Herawati ${ }^{*}$ \\ Accounting Departement, Universitas Pendidikan Ganesha
}

\begin{abstract}
The aims of this study are to determine: the difference of financial literacy level between students who have had experience in financial learning and who have not had experience in financial learning. The data for this study was collected through financial literacy test and questionnaire which was distributed through randomized sampling method. A total of 173 completed and usable questionnaire have been collected. The result shows that the level of financial literacy among accounting students comes under below optimal standard category. Students who have had financial learning experience have a higher level of financial literacy than students who have not. This study provides means to improve financial learning for accounting students in preparation for creating a prosperous future.
\end{abstract}

Keywords: Financial literacy, financial learning, accounting student

\section{Introduction}

Global economic development nowadays has brought a change effect onto its society economy system. One of the negative effects caused by it is the consumptive culture in the society, including the teenagers. The consumptive tendency that is actually quite normal for teenagers will turn into a problem if it has developed beyond control. If teenagers manage their money recklessly, it is possible that they carry on that attitude when they grow up. Aside from that, sometimes what the teenager's demand is beyond their parents' capability to provide as their fund source, that can lead to a new economy problem in the family. The matter whether someone is consumptive or not is a result of the minimum financial knowledge (financial literacy). Along with that, some researchers have shown that financial literacy has a significant impact on one's financial behavior $[1,2,3]$. Someone who has low financial literacy usually has a financial problem in his life.

* Corresponding author: aris herawati@yahoo.co.id 
Learning at university plays an important role in shaping students' financial literacy. Using various teaching methods, media, and appropriate learning sources students are expected to have the proficiency in finance so that they are prepared and capable of handling present as well as a more complex future life [4]. Some studies showed that learning finance at the university has an impact towards financial literacy $[4,5,6,7]$.

However, the research shows that level of financial literacy of college student comes within the low category event students majoring in Business disciplines $[6,7,8,9]$. Accounting is one of the majors in business disciplines with the most students and the number of enthusiasts is increasing each year. This is a challenge to escalate the quality of the graduates, and one of the means is by providing financial literacy comprehension through financial learning.

Financial literacy learning is not provided independently within the course curriculum. However, a number of finance subjects provided in the Accounting curriculum is relevant to the financial literacy concept. Some of the financial learning subjects are found in Financial Accounting, Financial Management, and Investment and Capital Market. Financial Accounting subject is taught from elementary level namely Introduction to Accounting 1 in the first semester to Advanced Financial Accounting 2 in the final semester, nevertheless, the financial literacy concept is more commonly encountered in Introduction to Accounting. An adequate financial learning process will enhance students' experience in managing their finance.

Based on the problem background above, the formulation of the proposed problem includes: (1) what is the financial literacy level of Accounting students, is it categorized as low, medium, or high? (2) does financial learning experience give an impact towards financial literacy level among Accounting students?

\section{Methods}

This research design is a quantitative research that reviews financial literacy level among students and the impact of financial learning experience towards student's financial literacy. Research population, in this case, is the entire students of Accounting at Universitas Pendidikan Ganesha. The number of samples of 174 students was taken through purposive sampling, by selecting classes with equivalent academic capability. Data was collected through financial literacy test [11] and analyzed using descriptive statistical analysis and ANOVA-OneWay. Descriptive statistic provides financial literacy level illustration whether it is considered as well literate, sufficient literate, or less literate. Classification of financial literacy is adapted from Chen and Volpe [11], who classified one's literacy level in this range: (1) Low group with the score $<60 \%$, (2) Medium group with the score between $60 \%$ and $79 \%$, and (3) High group with the score of $\geq 80 \%$. The next analysis is Anava-One Way that is used to find out the impact of financial learning experience towards the students' financial literacy level. Respondents are categorized into 3 groups according to their study semester. Group 1 consists of students in their second semester who only learn Introduction to Accounting, in this case, they are treated as a group with no financial learning experience.Group 2 consists of students in the fourth semester and group 3 consists of students in their sixth semester who have had experience in financial learning. Both group have learned accounting subject such as: Introduction to Accounting, Financial Management, Bank and Other Financial Institutions, also Investment and Capital Market. Before conducting hypothesis testing, a data normality and homogeneity test was performed beforehand. The result of normality test showed that all data was distributed normally with a significant rate higher than 0.05 . The result of homogeneity test showed that Levene statistic level (0.94) was higher than 0.05 which 
meant that the intergroup variants were homogenous. Hypothesis test was accepted if the value of $\operatorname{sig}<\alpha 0.05$. All statistical methods using SPSS for Windows 20.0

\section{Results and discussion}

The number of respondents involved in this research is 174 students consists of 55 second semester students as group 1, 58 fourth semester students as group 2 and 60 sixth semester students as group 3. The mean and standard deviation of financial literacy test result in each semester can be found in the following Table 1.

Table 1. Financial Literacy (FL) Test Result

\begin{tabular}{|l|c|c|c|c|c|c|c|}
\hline \multicolumn{7}{|c|}{ FINANCIAL LITERACY } \\
\hline Students & N & Mean & Min. & Max. & Std. Dev & $\begin{array}{c}\text { Std. Error } \\
\text { Mean }\end{array}$ & $\begin{array}{c}\text { Criteria/ } \\
\text { Level }\end{array}$ \\
\hline Group 1 & 55 & 48,36 & 22 & 82 & 14,162 & 1,910 & Low \\
\hline Group 2 & 58 & 59,72 & 26 & 88 & 12,214 & 1,873 & Low \\
\hline Group 3 & 60 & 59,24 & 29 & 82 & 11,318 & 1,461 & Low \\
\hline
\end{tabular}

Data processing outcome in Table 1 showed the mean of financial literacy test on second semester (group 1) students is the lowest compared to students in their fourth (group 2 ) and sixth semester (group 3). For students in their second semester, the mean of FL test is 48.36 points lower than the mean of FL test on students in their fourth semester, which was 59.72 while the mean of FL test on students in their sixth semester was 59.24. It is visible that the mean of FL test on students in their fourth semester was not that much different from sixth semester students. Based on the classification according to Chen and Volpe (1998), the financial literacy level of Accounting students is considered low yet it is close to medium, which is less than $60 \%$. The financial literacy average score for each component of financial literacy can be found in Table 2 .

Table 2. Financial Literacy Average Score for Each Component

\begin{tabular}{|ll|c|c|c|c|}
\hline & Financial Literacy Dimension & Group 1 & Group 2 & Group 3 & Average \\
\hline 1. & Financial basic concept & 61.01 & 72.80 & 71.11 & 68.31 \\
\hline 2. & Saving and investment & 34.85 & 43.97 & 46.39 & 41.73 \\
\hline 3. & Credit and debt management & 50.30 & 64.66 & 58.33 & 57.76 \\
\hline 4. & Insurance products & 47.27 & 57.47 & 61.11 & 55.29 \\
\hline
\end{tabular}

Based on Table 2, it can be viewed that the savings and investment component reached the lowest score (with the average of 41.49), while financial basic concept reached the highest score (with the average of 67.89). This indicated that students' comprehension in savings and investment concept is still low. Observing these 4 (four) components or financial literacy aspects, only financial basic concept that reached sufficient average of $68.31(>60)$. On the other hand, the other financial literacy aspects such as (1) savings and investment aspect with the average of 41.78 , (2) credit management comprehension with the average of 57.76, (3) insurance products comprehension with the average of 55.29, which is still considered low. These indicate that students have sufficient comprehension in 
financial basic concept aspect. Financial basic concept aspect has some indicators, which is comprehension on financial statement concept, time value concept of money, and income concept. Students can differentiate between the concept of "debit" and "credit" regarding good financial management, time value of money and adequate income management. However, viewed from other aspects, students have not comprehended them correctly. For example in investment and savings aspect; students have not comprehended the concept of investment in the capital market as well as its benefits and disadvantages of conventional savings. The case is similar in credit management and wise credit management. Regarding insurance comprehension, average scores were close to the minimum. In this case, it means that students have comprehended the importance of insurance, yet they have not understood the types of insurance and the coverage of each kind of insurance.

For further examination, hypothesis testing with Anova-One Way was performed. SPSS output produced calculation $\mathrm{F}$ value of 3397.558 for intercept and was significant at 0.05 , and so as $\mathrm{X}$ variable, in this case, financial learning experience, with $\mathrm{F}$ value of 14,676 and was significant at 0.05 . It can be concluded that financial learning experience for Accounting students affected financial literacy level.There is a difference in financial literacy level between students who have had adequate financial learning (Group 2 \& 3) and those who have not had sufficient financial learning (Group 1). The amount of adjusted $R$ square value of 0.137 means that the variability of students' financial literacy that can be rationalized by experiencing financial learning is at $13.7 \%$.

Research shows a significant difference in financial literacy level between students of semester 2 and those in semester 4 and 6. The lowest financial literacy level average was found in students in their second semester with the score of 48.36 and the highest was achieved by students in their fourth semester with the average of 59.72, not so much different from students in their sixth semester, which ranged at the score of 59.24. This proves that students who have gone through financial learning have better financial literacy from those who have not been through financial learning. However, research shows that there is no significant difference between students of the fourth semester and sixth semester. Even financial literacy average score of students of the fourth semester is better than those in the sixth semester $(59.72>59.24)$. This indicates those four subjects are highly relevant associated with aspects of financial literacy, while other accounting subjects that are taught in the fifth semester and sixth semester do not provide a significant contribution towards students' financial literacy level.

Financial learning plays a highly important role for students to have the ability to comprehend, judge, and act in their financial interests. Undoubtedly financial knowledge as a result of financial learning, its success theoretically is related to teaching and learning process. Learning process and assessment technique used by lectors also determine students' success in comprehending and implementing material received in their daily life [10]. Learning will achieve a better result when provided with relevant lessons using active learning method. Important skill has to be put into action in order to have it fully embedded within students and become purposeful for their life. This research result comports with the research conducted [6,7], which stated that there is influence between financial learning at university towards financial literacy in the cognitive aspect.

\section{Conclusion}

According to the exposition above, several items can be concluded as follows.First, financial literacy level of Accounting students is still considered low $(<60)$. Second, there is a difference in the level of financial literacy among students who have had a financial learning experience and those who have not.Students who have had financial learning experience have higher financial literacy level compared to those who have not.The low 
financial literacy level among students impacts on the need to have strategic efforts to elevate students' financial literacy. One of them is by upgrading the financial learning quality at the university. A number of financial materials taught does not matter if it is not related to financial literacy aspect since it will not provide a positive impact for students to enhance their financial literacy. Therefore, it is necessary to provide real cases that correspond to personal financial aspect. Besides, this research has also proven that financial learning in Accounting Department, especially in Introduction to Accounting, Financial Management, Bank and Other Financial Institutions and Investment and Capital Market subjects, produce significant contribution towards students' financial literacy.Accordingly, these four subjects are expected to apply financial literacy concept within its learning. This research has limitation in terms of samples used, which only covered one institution. Furthermore, financial literacy level ignores other factors suspected to have a more powerful impact, such as family and social demography status of students.

\section{References}

1 Danes, S. M. \&Haberman, H. R,Teen Financial Knowledge, Self-Efficacy, and Behavior: A Gendered View. Financial Counseling and Planning. 18(2): 48-60 Retrieved from htpp://www.afcpe.org/assets/pdf/7-2866-volume-18-issue-2.pdf, (2007)

2 Vyviyan, Victoria; Blue, Levon; \& Brimble, Mark, "Factors that Influence Fianncial Capability and Effectiveness: Exploring Financial Councelors Perspectives" Australian Accounting, Business and Finance Journal, Vol.8,Iss 4, 2014,3-22, Retrieved from htpp://ro.ouw.edu.au/aabfj/vol8/iss4/2, (2014)

3 Kozina,Franca Lovsin dan Ponikvar,Nina, "Students' Confidence In Their Financial Manajemen Abilities : The Role Of Socio-Demographic Characteristics And Education”. Journal of Problems of Education, Vol.58.h.108, Retrieved from htpp:// htpp://www.cgsnet.org/ckfinder/userfiles/files/PracticesofCollege Students_Final.pdf, (2014)

4 Lutfi \& Iramani, Financial Literacy Among University Student and Its Impli-cations to the Teaching Method. Paper presented at Annual SEAAIR Conference STIE Perbanas, Surabaya (2008)

5 Jhonson, E \& Margaret, S. S, From Financial Literacy to Financial Capability Among The Young. Journal of Sociology and Social Welfare, 34:119-146. Retrieved from htpp://www.usc.edu/dept/cheap/HRYANG/publications/110.pdf (2007)

6 Susanti, Pentingnya Literasi Keuangan Bagi Generasi Muda di Surabaya, Paper presented at SNE" Pembangunan Manusia Melalui Pendidikan Dalam Menghadapi ASEAN Economic Community 2015" Surabaya, 3 Mei 2014,h.278, Retrieved from htpp://fe.unesa.ac.id/sne1014, (2014)

7 Widayati,Irin, Faktor-Faktor yang Mempengaruhi Literasi Keuangan Mahasiswa Fakultas Ekonomi dan Bisnis Universitas Brawijaya. ASSET :Jurnal Akuntansi dan Pendidikan, Vol.1,No 1, Oktober 2012 (2012)

8 Nidar,S.R.,\& Bestari,S, Personal Financial Literacy Among University Students (Case Study at Padjajaran Universitas Students, Bandung, Indonesia). World Journal of Social Science (2)4: 162-171 (2012)

9 Layli, N. 2013. Pengaruh Literasi Keuangan terhadap Perilaku Mahasiswa dalam Mengelola Keuangan. Artikel. JPA UM Malang. Vol 1. No.4. Hal. 277-285. (2013) 
10 Trianto, Mendesain Model PembelajaranInovatif-Progresif. Jakarta: Kencana Pre-nada Media Group, (2009)

11 Huston,S.J, Measuring Financial Literacy.Journal of Consumeer Affairs, 44 (2) : 296316, Retrieved from htpp:// onlinelibrary.wiley.com (2010) 